\title{
APLIKASI REGRESI KUANTIL PADA KASUS DBD DI KOTA PALU SULAWESI TENGAH
}

\author{
N. Idris ${ }^{1}$, Rais ${ }^{2}$, dan I. T. Utami ${ }^{3}$ \\ 1,2,3 Program Studi Matematika Jurusan Matematika FMIPA Universitas Tadulako \\ Jalan Soekarno-Hatta KM. 09 Tondo, Palu 94118, Indonesia \\ nurdiantiidris@gmail.com¹, rais76untad@yahoo.com², triutami.iut@gmail.com³
}

\begin{abstract}
Palu city is one of the cities with unstable changes of natural conditions. The natural conditions such as the frequency of rainy day, temperature and humidity which are always changeable bring bad impacts and will cause of diseases especially dengue hemorrhagic fever (DBD). Therefore, it needs an action to recognise whether or not the natural condition factor influences the spread of DBD and determines what factors of the natural condition can influence the spread of DBD. This research applied quantile regression in the case of DBD in Palu city. Quantile regression is an analysis technique regarding to the functional relationship between one dependent variable with one or more independent variables which can provide accurate and stable results even though there will be outliers. Based on the result of the research, it is obtained that the natural condition factor affected the spread of DBD. This is because from 3 natural conditions only 11 significant or influential quantiles on the tested data, the quantiles are 0,$30 ; 0,35 ; 0,40 ; 0,45 ; 0,50 ; 0,55 ; 0,60 ; 0,65 ; 0,70 ; 0,75$ and 0,80 . Meanwhile the most influential factor of natural conditions in spreading DBD is the frequency of rainy day because it has positive which means that 1 progress of percentage will increase the quantity of DBD case.
\end{abstract}

Keywords : : DBD, Frequency of Rainy Day, Humidity, Natural Condition, Quantile Regression, Temperature.

\section{ABSTRAK}

Kota palu merupakan salah satu kota yang memiliki perubahan kondisi alam yang tidak stabil. Kondisi alam seperti frekuensi hari hujan, suhu dan kelembaban yang berubah-ubah membawa dampak yang tidak baik dan akan menimbulkan penyakit khususnya demam berdarah dengue (DBD). Oleh karena itu diperlukan suatu tindakan untuk mengetahui apakah faktor kondisi alam berpengaruh terhadap penyebaran penyakit DBD dan menentukan faktor kondisi alam apa saja yang berpengaruh terhadap penyebaran penyakit DBD. Penelitian ini, mengaplikasikan regresi kuantil pada kasus DBD di kota palu. Regresi kuantil merupakan teknik analisis tentang hubungan fungsional antara satu variabel tak bebas dengan satu atau lebih variabel bebas yang dapat memberikan hasil yang tepat dan stabil meski terdapat pencilan. Dari hasil penelitian diperoleh faktor kondisi alam berpengaruh terhadap penyebaran penyakit DBD. Hal ini terjadi karena dari ke 3 faktor kondisi alam yang digunakan dalam penelitian diperoleh 11 kuantil yang signifikan atau berpengaruh terhadap data yang diuji, kuantil tersebut ialah 0,$30 ; 0,35 ; 0,40 ; 0,45 ; 0,50 ; 0,55 ; 0,60 ; 0,65 ; 0,70 ; 0,75$ dan 0,80. Sementara faktor kondisi alam yang sangat berpengaruh terhadap penyebaran penyakit DBD adalah frekuensi hari hujan karena bernilai positif yang berarti kenaikan 1 satuan presentasenya akan meningkatkan jumlah kasus DBD.

Kata kunci : DBD, Frekuensi Hari Hujan, Kelembaban, Kondisi Alam, Regresi Kuantil, Suhu. 


\section{PENDAHULUAN}

\subsection{Latar Belakang}

Salah satu teknik analisis data dalam ilmu statistika yang sedang berkembang belakangan ini adalah analisis regresi. Teknik analisis data ini digunakan untuk mengetahui hubungan fungsional antara satu variabel yang disebut variabel tak bebas atau variabel yang dijelaskan $(Y)$ dan satu atau lebih variabel lain yang disebut variabel bebas atau variabel penjelas $(\mathrm{X})$. Dalam analisis regresi ada beberapa metode yang dapat digunakan untuk permasalahan tersebut, namun dalam penelitian ini penulis akan membahas tentang hubungan fungsional pada Regresi Kuantil.

Regresi kuantil adalah metode yang berguna untuk mengestimasi parameter, metode ini tidak mudah terpengaruh oleh kehadiran pencilan sehingga pencilan menjauh dan tidak mengganggu kestabilan data yang diperoleh. Selain itu, metode ini dapat memberikan hasil yang tepat dan stabil pada kehadiran pencilan serta dapat membatasi pengaruh dari pencilan (Furno, 2007). Kelebihan dari regresi kuantil salah satunya adalah dapat meminimumkan pengaruh dari pencilan (Koenker \& Bassett, 1978). Penaksir parameter yang digunakan dalam regresi kuantil sama dengan metode OLS yaitu meminimumkan jumlah kuadrat sisaan (Hao \& Naiman, 2007).

Demam Berdarah Dangue (DBD) merupakan contoh kasus yang penulis gunakan untuk menelaah hubungan antara variabel tak bebas dengan satu atau lebih variabel tak bebas. DBD adalah infeksi yang disebabkan oleh virus dari Genus Flavivirus yang tergolong dalam Famili Flaviviridae (berkahmeidra.blogspot.com, 07 April 2012). Virus tersebut dibawa oleh nyamuk Aedes Aegypti dan ditularkan saat nyamuk menghisap darah kita.

Nyamuk Aedes Aegypti lebih suka bersarang di air bersih, oleh karena itu kasus demam berdarah biasanya muncul pada setiap musim penghujan karena terdapat genangan air di mana-mana. Faktor kondisi alam seperti frekuensi hari hujan, suhu dan kelembaban yang meningkat pada setiap musim penghujan membuat perkembang biakan nyamuk aedes aegypti dan penyebaran penyakit DBD menjadi lebih cepat. Beberapa gejala yang ditimbulkan pada penyakit DBD yaitu demam, lesu, nyeri perut, tanda pendarahan dan masih banyak lagi. DBD merupakan salah satu penyakit yang jika tidak segera ditangani dengan baik akan berujung pada akibat yang fatal, yaitu kematian. Karena tingginya resiko yang ditimbulkan dari penyebaran penyakit DBD, membuat penulis tertarik untuk mengaplikasikan regresi kuantil pada kasus tersebut. 


\section{METODE PENELITIAN}

Prosedur dari Penelitian ini adalah sebagai berikut:

1. Mengumpulkan data yang akan digunakan pada penelitian ini, yaitu data kasus DBD dan kondisi alam kota Palu tahun 2011-2015.

2. Menstandarisasi data karena skala dari masing-masing data kasus DBD dan kondisi alam tersebut berbeda.

3. Mengeksplorasi data, maksud dari eksplorasi data ini adalah untuk mengetahui pencilan data.

4. Mengestimasi kuantil pada pada nilai $\tau=0,05 ; 0,10 ; 0,15 ; 0,20 ; 0,25 ; 0,30 ; 0,35 ; 0,40 ; 0,45$; 0,$50 ; 0,55 ; 0,60 ; 0,65 ; 0,70 ; 0,75 ; 0,80 ; 0,85 ; 0,90$ dan 0,95 .

5. Menduga parameter regresi kuantil.

6. Mencari selang kepercayaan menggunakan proses bootstrap untuk mengasumsikan galat acak dan resampel dari residu. Resampling langsung dari proses regresi kuantil penuh adalah suatu mekanisme resampling yang lebih menarik (Koenker, 1994).

7. Menguji hipotesis.

8. Kesimpulan.

9. Selesai.

\section{HASIL DAN PEMBAHASAN}

\subsection{Standarisasi Data}

Standarisasi dilakukan pada setiap peubah karena skala dari masing-masing peubah tersebut berbeda.

$$
\begin{aligned}
Z_{i} & =\text { Variabel yang telah distandarisasikan } \\
x_{p} & =\text { Variabel observasi } \\
\bar{x}_{p} & =\text { Rata-rata dari variabel observasi } \\
S_{p} & =\text { Variansi untuk variabel observasi } \\
Z_{i} & =\frac{\left(x_{1,1}-\bar{x}_{1}\right)}{\sqrt{S_{p}}} \\
& =\frac{20-15,25}{\sqrt{5,598501616^{2}}} \\
& =\frac{4,75}{5,598501616} \\
& =0,8484413
\end{aligned}
$$

Hasil standarisasi lengkap didapat melalui program Microsoft Excel 2010. 


\subsection{Eksplorasi Data}

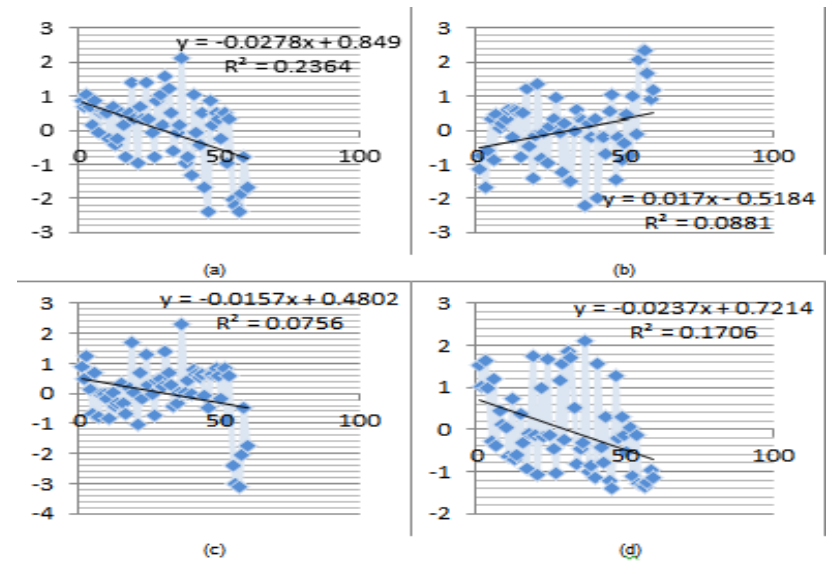

Gambar 1 : Scatter Plot frekuesi hari hujan (a), suhu (b), kelembaban (c) dan kasus DBD

Proses eksplorasi data pada penelitian ini menggunakan Microsoft Excel 2010. Hasil eksplorasi data menunjukan adanya pencilan, hal ini terdeteksi oleh gambar scatter plot sebelumnya. Pencilan data dapat dilihat pada titik yang menyendiri pada data frekuensi hari hujan dan kelembaban. Pada data-data tersebut hanya ada 1 pencilan data yang terlihat jauh dari data yang lain yaitu dititik 2,1 pada frekuensi hari hujan, titik -2,2 pada suhu, titik 2,3 pada kelembaban dan titik 2,2 kasus DBD. Sementara itu sebaran data frekuensi hari hujan $\left(x_{1}\right)$ menunjukan persamaan $y=-0,0278 x+0,849$ dengan $R^{2}=0,2364$. Sebaran data suhu $\left(x_{2}\right)$ menunjukan persamaan $y=0,017 x-0,5184$ dengan $R^{2}=0,0881$. Sebaran data kelembaban $\left(x_{3}\right)$ menunjukan persamaan $y=-0,0157 x+0,4802$ dengan $R^{2}=0,0756$. Sementara sebaran data kasus DBD $(y)$ menunjukan persamaan $y=-0,0237 x+0,7214$ dengan $R^{2}=0,1706$.

\subsection{Estimasi Nilai Kuantil}

Estimasi kuantil dilakukan untuk menggambarkan keberagaman model dari regresi kuantil tersebut. Dalam penelitian ini $\tau$ yang digunakan ialah 0,$05 ; 0,10 ; 0,15 ; 0,20 ; 0,25$; 0,$30 ; 0,35 ; 0,40 ; 0,45 ; 0,50 ; 0,55 ; 0,60 ; 0,65 ; 0,70 ; 0,75 ; 0,80 ; 0,85 ; 0,90$ dan 0,95 .

\subsection{Menduga Parameter}

Tabel 1 : Penduga Parameter Regresi Kuantil

\begin{tabular}{|c|c|c|c|c|}
\hline$\tau$ & Intercept & Frekuensi Hari Hujan & Suhu & Kelembaban \\
\hline 0,05 & $-0,45176$ & 0,79984 & 0,05152 & 0,02786 \\
\hline 0,10 & $-0,39711$ & 0,64333 & $-0,16737$ & $-0,02733$ \\
\hline 0,15 & $-0,34780$ & 0,66923 & $-0,28710$ & $-0,14598$ \\
\hline 0,20 & $-0,32488$ & 0,64211 & $-0,37818$ & $-0,20781$ \\
\hline 0,25 & $-0,26947$ & 0,66452 & $-0,51884$ & $-0,33796$ \\
\hline
\end{tabular}




\begin{tabular}{|l|l|l|l|l|}
\hline 0,30 & $-0,19702$ & 0,68968 & $-0,72072$ & 0,51411 \\
\hline 0,35 & $-0,17812$ & 0,70431 & $-0,73844$ & $-0,54843$ \\
\hline 0,40 & $-0,17706$ & 0,70549 & $-0,73787$ & $-0,54982$ \\
\hline 0,45 & $-0,09596$ & 0,67021 & $-0,81474$ & $-0,58476$ \\
\hline 0,50 & $-0,07594$ & 0,70804 & $-0,85463$ & $-0,63687$ \\
\hline 0,55 & 0,00121 & 0,60685 & $-0,00155$ & $-0,74640$ \\
\hline 0,60 & 0,05553 & 0,65795 & $-0,96734$ & $-0,73781$ \\
\hline 0,65 & 0,08075 & 0,68938 & $-0,92237$ & $-0,71717$ \\
\hline 0,70 & 0,17574 & 0,52025 & $-1,02910$ & $-0,62867$ \\
\hline 0,75 & 0,24126 & 0,58082 & $-0,96925$ & $-0,65433$ \\
\hline 0,80 & 0,26728 & 0,52539 & $-0,94683$ & $-0,58795$ \\
\hline 0,85 & 0,38493 & 0,50208 & $-0,78843$ & $-0,40902$ \\
\hline 0,90 & 0,54772 & 0,69497 & $-0,34389$ & $-0,15045$ \\
\hline 0,95 & 0,59017 & 0,73284 & $-0,30401$ & $-0,16246$ \\
\hline
\end{tabular}

Pada Tabel 1 dapat dilihat bahwa nilai intercept semakin besar dengan semakin besarnya kuantil yang dipilih. Nilai frekuensi hari hujan mengalami naik turun yang tidak beraturan dari kuantil 0,05-0,95. Sementara nilai suhu dan kelembaban bernilai positif pada kuantil 0,05 dan terus bernilai negatif dari kuantil 0,10-0,95. Berikut adalah persamaan model dari masing-masing kuantil :

$$
\begin{gathered}
y_{0,05}=-0,45176+0,79984 x_{1}+0,05152 x_{2}+0,02786 x_{3} \\
y_{0,10}=-0,39711+0,64333 x_{1}-0,16737 x_{2}-0,02733 x_{3} \\
y_{0,15}=-0,34780+0,66923 x_{1}-0,28710 x_{2}-0,14598 x_{3} \\
y_{0,20}=-0,32488+0,64211 x_{1}-0,37818 x_{2}-0,20781 x_{3} \\
y_{0,25}=-0,26947+0,66452 x_{1}-0,51884 x_{2}-0,33796 x_{3} \\
y_{0,30}=-0,19702+0,68968 x_{1}-0,72072 x_{2}-0,51411 x_{3} \\
y_{0,35}=-0,17812+0,70431 x_{1}-0,73844 x_{2}-0,54843 x_{3} \\
y_{0,40}=-0,17706+0,70549 x_{1}-0,73787 x_{2}-0,54982 x_{3} \\
y_{0,45}=-0,09596+0,67021 x_{1}-0,81474 x_{2}-0,584761 x_{3} \\
y_{0,50}=-0,07594+0,70804 x_{1}-0,85463 x_{2}-0,63687 x_{3} \\
y_{0,55}=0,00121+0,60685 x_{1}-1,00155 x_{2}-0,74640 x_{3} \\
y_{0,60}=0,05553+0,65795 x_{1}-0,96734 x_{2}-0,73781 x_{3} \\
y_{0,65}=0,08075+0,68938 x_{1}-0,92237 x_{2}-0,71717 x_{3} \\
y_{0,70}=0,17574+0,52025 x_{1}-1,02910 x_{2}-0,62867 x_{3} \\
y_{0,75}=0,24126+0,58082 x_{1}-0,96925 x_{2}-0,65433 x_{3} \\
y_{0,80}=0,26728+0,52539 x_{1}-0,94683 x_{2}-0,58795 x_{3} \\
y_{0,85}=0,38493+0,50208 x_{1}-0,78843 x_{2}-0,40902 x_{3} \\
y_{0,90}=0,54772+0,69497 x_{1}-0,34389 x_{2}-0,15045 x_{3} \\
y_{0,95}=0,59017+0,73284 x_{1}-0,30401 x_{2}-0,16246 x_{3}
\end{gathered}
$$




\subsection{Selang Kepercayaan}

Tabel 2 : Selang kepercayaan bagi parameter $\beta_{i}$

\begin{tabular}{|c|c|c|c|c|c|}
\hline & $\tau$ & Intercept & Frekuensi Hari & Suhu & Kelembaban \\
\hline 005 & Batas Bawah & $-0,45347$ & 0,39883 & $-1,15145$ & $-0,92522$ \\
\hline & Batas Atas & $-0,39882$ & 1,28581 & 0,17849 & 0,09648 \\
\hline & Batas Bawah & $-0,45185$ & 0,38716 & $-1,06400$ & $-0,66772$ \\
\hline 0,10 & Batas Atas & $-0,34858$ & 0,95555 & 0,13025 & 0,09511 \\
\hline & Batas Bawah & $-0,40748$ & 0,39424 & $-1,01641$ & $-0,65318$ \\
\hline 0,10 & Batas Atas & $-0,27461$ & 0,92216 & 0,00543 & 0,07312 \\
\hline & Batas Bawah & $-0,35632$ & 0,40791 & $-0,97232$ & $-0,6675$ \\
\hline $0,2 v$ & Batas Atas & $-0,22388$ & 0,92983 & $-0,15668$ & 0,03854 \\
\hline & Batas Bawah & $-0,34730$ & 0,39323 & $-0,84824$ & $-0,65981$ \\
\hline 0,20 & Batas Atas & $-0,17984$ & 0,82051 & $-0,18713$ & $-0,04034$ \\
\hline 030 & Batas Bawah & $-0,31808$ & 0,35946 & $-0,88627$ & $-0,69662$ \\
\hline 0,00 & Batas Atas & $-0,17723$ & 0,79579 & $-0,28362$ & $-0,13927$ \\
\hline 035 & Batas Bawah & $-0,26844$ & 0,42314 & $-0,90064$ & $-0,83729$ \\
\hline ט, & Batas Atas & $-0,09711$ & 0,80375 & $-0,42170$ & $-0,14183$ \\
\hline & Batas Bawah & $-0,19611$ & 0,47315 & $-0,96195$ & $-0,87940$ \\
\hline 0,40 & Batas Atas & $-0,06227$ & 0,79878 & $-0,57695$ & $-0,13902$ \\
\hline & Batas Bawah & $-0,17806$ & 0,50986 & $-1,03111$ & $-0,91873$ \\
\hline & Batas Atas & 0,00190 & 0,81760 & $-0,68271$ & $-0,28819$ \\
\hline 050 & Batas Bawah & $-0,15387$ & 0,37779 & $-1,11491$ & $-0,90913$ \\
\hline & Batas Atas & 0,04630 & 0,93762 & $-0,69925$ & $-0,25516$ \\
\hline 055 & Batas Bawah & $-0,09702$ & 0,44086 & $-1,26058$ & $-0,91334$ \\
\hline & Batas Atas & 0,08400 & 0,90421 & $-0,67630$ & $-0,31465$ \\
\hline 0 & Batas Bawah & $-0,17712$ & 0,44668 & $-1,26547$ & $-0,89512$ \\
\hline 0,00 & Batas Atas & $-0,07271$ & 0,89551 & $-0,68235$ & $-0,35794$ \\
\hline & Batas Bawah & 0,00258 & 0,43199 & $-1,27111$ & $-0,93043$ \\
\hline & Batas Atas & 0,23260 & 0,93463 & $-0,66402$ & $-0,29490$ \\
\hline & Batas Bawah & 0,06623 & 0,30539 & $-1,30700$ & $-0,91854$ \\
\hline 0,10 & Batas Atas & 0,26490 & 1,06551 & $-0,73063$ & $-0,31388$ \\
\hline 07 & Batas Bawah & 0,10061 & 0,33150 & $-1,29907$ & $-0,87732$ \\
\hline 0,10 & Batas Atas & 0,37372 & 1,01903 & $-0,55624$ & $-0,21994$ \\
\hline 08 & Batas Bawah & 0,20938 & 0,35434 & $-1,25506$ & $-0,78269$ \\
\hline 0,00 & Batas Atas & 0,45896 & 1,86762 & $-0,28561$ & $-0,22572$ \\
\hline 0,85 & Batas Bawah & 0,25062 & 0,35640 & $-1,25772$ & $-0,69318$ \\
\hline
\end{tabular}




\begin{tabular}{|l|l|l|l|l|l|} 
& Batas Atas & 0,58015 & 0,91893 & $-0,19715$ & $-0,19255$ \\
\hline \multirow{2}{*}{0,90} & Batas Bawah & 0,37864 & $-0,00855$ & $-1,23203$ & $-0,72462$ \\
\cline { 2 - 6 } & Batas Atas & 0,60375 & 0,92736 & $-0,20151$ & $-0,11090$ \\
\hline \multirow{2}{*}{0,95} & Batas Bawah & 0,55907 & $-0,12509$ & $-1,33789$ & $-0,27366$ \\
\cline { 2 - 6 } & Batas Atas & 0,64595 & 0,73667 & $-0,29501$ & $-0,05971$ \\
\hline
\end{tabular}

Berdasarkan Tabel 2 dapat dilihat bahwa selang kepercayaan bagi penduga parameter $\beta_{i}$ memiliki nilai yang bervariasi. Intercept bernilai negatif di batas bawah dan batas atas pada kuantil 0,05-0,40 dan bernilai positif di batas bawah dan batas atas pada kuantil $0,65-0,95$. Frekuensi hari hujan bernilai positif di batas bawah dan batas atas pada kuantil $0,05-0,85$ dan benilai negatif di batas bawah dan positif di batas atas pada kuantil 0,90-0,95. Sementara suhu dan kelembaban bernilai negatif di batas bawah dan positif di batas atas pada kuantil 0,05-0,15 dan bernilai negaif di batas bawah dan batas atas pada kuantil 0,20-0,95.

\subsection{Uji Hipotesis}

3.6.1. Hipotesis

$$
\begin{aligned}
& H_{0}: \beta_{j}=0 \\
& H_{1}: \beta_{j} \neq 0 \text { dengan } \mathrm{j}=1,2,3, \ldots, \mathrm{p} .
\end{aligned}
$$

3.6.2. Statistik uji

$$
T_{W}(\tau)=\hat{\beta}_{2}^{\prime}(\tau) \sum(\tau)^{-1} \hat{\beta}_{2}(\tau)
$$

3.6.3. Kriteria Pengujian

$H_{0}$ ditolak jika nilai $\operatorname{Pr}(>|\mathrm{t}|) \geq \alpha, \alpha=5 \%$ atau 0,05 .

a. $\tau=0,05$

Value Std. Error $t$ value $\operatorname{Pr}(>|t|)$

(Intercept) $-0.45176 \quad 0.03218 \quad-14.037300 .00000$

$\begin{array}{lllllll}\text { frekuensi } & 0.79984 & 0.13642 & 5.86323 & 0.00000 & \text { frekuensi }\end{array}$

\begin{tabular}{llllll|l|l|l|l} 
suhu & 0.05152 & 0.28694 & 0.17953 & 0.85817 & suhu
\end{tabular}

klmbbn

$0.02786 \quad 0.20330$

$\begin{array}{lll}0.13703 & 0.89150 \mathrm{klmbbn}\end{array}$ b. $\tau=0,10$

Value Std. Error $t$ value $\operatorname{Pr}(>\mid t)$

t) $-0.397110 .04335 \quad-9.160380 .00000$

$\begin{array}{lllll}0.64333 & 0.13479 & 4.77296 & 0.00001\end{array}$

$\begin{array}{lllll}-0.16737 & 0.29439 & -0.56853 & 0.57195\end{array}$

$\begin{array}{lllll}-0.02733 & 0.21107 & -0.12948 & 0.89744\end{array}$

d. $\tau=0,20$

C. $\tau=0,15$

Value Std. Error t value $\operatorname{Pr}(>\mid t)$

$\begin{array}{llllllllll}\text { (Intercept) }-0.34780 & 0.05240 & -6.63680 & 0.00000 & \text { (Intercept) }-0.32488 & 0.05885 & -5.52051 & 0.00000\end{array}$

$\begin{array}{llllllllllll}\text { frekuensi } & 0.66923 & 0.13067 & 5.12142 & 0.00000 & \text { frekuensi } & 0.64211 & 0.12778 & 5.02496 & 0.00001\end{array}$

\begin{tabular}{llllll|lllllll} 
suhu & -0.28710 & 0.25718 & -1.11634 & 0.26904 & suhu & -0.37818 & 0.24537 & -1.54129 & 0.12888
\end{tabular}

$\begin{array}{llllllllll}\text { klmbbn } & -0.14598 & 0.20090 & -0.72662 & 0.47048 & \text { klmbbn } & -0.20781 & 0.21038 & -0.98780 & 0.32750\end{array}$

e. $\tau=0,25$

Value Std. Error t value $\operatorname{Pr}(>|t|)$

(Intercept) - $0.26947 \quad 0.06256 \quad-4.30703 \quad 0.00007$

$\begin{array}{llllll}\text { frekuensi } & 0.66452 & 0.13770 & 4.82587 & 0.00001\end{array}$

$\begin{array}{llllll}\text { suhu } & -0.51884 & 0.22728 & -2.28282 & 0.02626\end{array}$

$\begin{array}{lllll}\text { klmbbn } & -0.33796 & 0.21111 & -1.60088 & 0.11503\end{array}$

g. $\tau=0,35$

Value Std. Error t value $\operatorname{Pr}(>|t|)$

(Intercept) - $0.17812 \quad 0.06836 \quad-2.60552 \quad 0.01173$

$\begin{array}{llllll}\text { frekuensi } & 0.70431 & 0.11975 & 5.88167 & 0.00000\end{array}$

$\begin{array}{llllll}\text { suhu } & -0.73844 & 0.18295 & -4.03621 & 0.00017\end{array}$

klmbbn f. $\tau=0,30$

Value Std. Error t value $\operatorname{Pr}(>|t|)$

$\begin{array}{lllll}\text { (Intercept) }-0.19702 & 0.06036 & -3.26417 & 0.00187\end{array}$

$\begin{array}{lllllll}\text { frekuensi } & 0.68968 & 0.13974 & 4.93545 & 0.00001\end{array}$

$\begin{array}{lllllll}\text { suhu } & -0.72072 & 0.18711 & -3.85184 & 0.00030\end{array}$

$\begin{array}{llllll}\text { klmbbn } & -0.51411 & 0.19260 & -2.66926 & 0.00993\end{array}$

h. $\tau=0,40$

Value Std. Error $t$ value $\operatorname{Pr}(>\mid t)$ $\begin{array}{lllll}\text { (Intercept) }-0.17706 & 0.06317 & -2.80311 & 0.00694\end{array}$

frekuensi $\quad 0.705490 .12634 \quad 5.584010 .00000$

$\begin{array}{lllllll}\text { suhu } & -0.73787 & 0.17214 & -4.28642 & 0.00007\end{array}$

$\begin{array}{llllll}\text { klmbbn } & -0.54982 & 0.20856 & -2.63625 & 0.01083\end{array}$ 
i. $\tau=0,45$

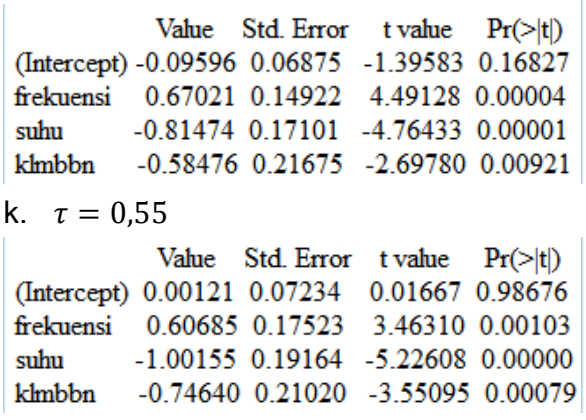

m. $\tau=0,65$

Value Std. Error $\mathrm{t}$ value $\operatorname{Pr}(>|\mathrm{t}|)$

$\begin{array}{llllll}\text { (Intercept) } & 0.08075 & 0.08107 & 0.99609 & 0.32349\end{array}$

$\begin{array}{llllll}\text { frekuensi } & 0.68938 & 0.19207 & 3.58927 & 0.00070\end{array}$

$\begin{array}{llllll}\text { suhu } & -0.92237 & 0.21349 & -4.32051 & 0.00006\end{array}$

$\begin{array}{llllll}\text { klmbbn } & -0.71717 & 0.26333 & -2.72348 & 0.00860\end{array}$

o. $\tau=0,75$

Value Std. Error $t$ value $\operatorname{Pr}(>|t|)$ $\begin{array}{llllll}\text { (Intercept) } & 0.24126 & 0.08230 & 2.93162 & 0.00488\end{array}$

$\begin{array}{llllll}\text { frekuensi } & 0.58082 & 0.21619 & 2.68667 & 0.00948\end{array}$ $\begin{array}{llllll}\text { suhu } & -0.96925 & 0.25633 & -3.78121 & 0.00038\end{array}$ $\begin{array}{llllll}\text { klmbbn } & -0.65433 & 0.23887 & -2.73927 & 0.00824\end{array}$

q. $\tau=0,85$

Value Std. Error $t$ value $\operatorname{Pr}(>|t|)$ $\begin{array}{lllll}\text { (Intercept) } & 0.38493 & 0.09160 & 4.20242 & 0.00010\end{array}$ $\begin{array}{llllll}\text { frekuensi } & 0.50208 & 0.25491 & 1.96960 & 0.05384\end{array}$ $\begin{array}{llllll}\text { suhu } & -0.78843 & 0.32504 & -2.42563 & 0.01853\end{array}$ $\begin{array}{lllll}\text { klmbbn } & -0.40902 & 0.25443 & -1.60759 & 0.11355\end{array}$ s. $\tau=0,95$

Value Std. Error t value $\operatorname{Pr}(>t)$ $\begin{array}{lllll}\text { (Intercept) } & 0.59017 & 0.07494 & 7.87540 & 0.00000\end{array}$ $\begin{array}{lllllll}\text { frekuensi } & 0.73284 & 0.20283 & 3.61307 & 0.00065\end{array}$ $\begin{array}{llllll}\text { suhu } & -0.30401 & 0.28438 & -1.06905 & 0.28963\end{array}$ $\begin{array}{llllll}\text { klmbbn } & -0.16246 & 0.26635 & -0.60996 & 0.54436\end{array}$ j. $\tau=0,50$

Value Std. Error t value $\operatorname{Pr}(>|t|)$

(Intercept) $-0.07594 \quad 0.07176 \quad-1.058190 .29451$

$\begin{array}{llllll}\text { frekuensi } & 0.70804 & 0.16670 & 4.24746 & 0.00008\end{array}$

$\begin{array}{lllllll}\text { suhu } & -0.85463 & 0.16881 & -5.06274 & 0.00000\end{array}$

$\begin{array}{llllll}\text { klmbbn } & -0.63687 & 0.18948 & -3.36110 & 0.00140\end{array}$

I. $\tau=0,60$

Value Std. Error t value $\operatorname{Pr}(>|t|)$

$\begin{array}{llllll}\text { (Intercept) } & 0.05553 & 0.08126 & 0.68337 & 0.49719\end{array}$

$\begin{array}{llllll}\text { frekuensi } & 0.65795 & 0.17288 & 3.80578 & 0.00035\end{array}$

$\begin{array}{llllll}\text { suhu } & -0.96734 & 0.19623 & -4.92966 & 0.00001\end{array}$

$\begin{array}{llllll}\text { klmbbn } & -0.73781 & 0.22172 & -3.32769 & 0.00155\end{array}$

n. $\tau=0,70$

Value Std. Error t value $\operatorname{Pr}(>t)$

$\begin{array}{llllll}\text { (Intercept) } & 0.17574 & 0.07721 & 2.27601 & 0.02669\end{array}$

$\begin{array}{llllll}\text { frekuensi } & 0.52025 & 0.21112 & 2.46430 & 0.01682\end{array}$

$\begin{array}{llllll}\text { suhu } & -1.02910 & 0.23276 & -4.42124 & 0.00005\end{array}$

$\begin{array}{llllll}\text { klmbbn } & -0.62867 & 0.23872 & -2.63348 & 0.01091\end{array}$

p. $\tau=0,80$

Value Std. Error $t$ value $\operatorname{Pr}(>t)$

$\begin{array}{llllll}\text { (Intercept) } & 0.26728 & 0.08688 & 3.07655 & 0.00324\end{array}$

$\begin{array}{llllll}\text { frekuensi } & 0.52539 & 0.24151 & 2.17543 & 0.03384\end{array}$

$\begin{array}{llllll}\text { suhu } & -0.94683 & 0.29208 & -3.24168 & 0.00200\end{array}$

$\begin{array}{llllll}\text { klmbbn } & -0.58795 & 0.25841 & -2.27525 & 0.02674\end{array}$

r. $\tau=0,90$

Value Std. Error t value $\operatorname{Pr}(>|t|)$

$\begin{array}{llllll}\text { (Intercept) } & 0.54772 & 0.10318 & 5.30867 & 0.00000\end{array}$

$\begin{array}{llllll}\text { frekuensi } & 0.69497 & 0.24093 & 2.88454 & 0.00555\end{array}$

$\begin{array}{llllll}\text { suhu } & -0.34389 & 0.34226 & -1.00475 & 0.31934\end{array}$

$\begin{array}{llllll}\text { klmbbn } & -0.15045 & 0.25492 & -0.59019 & 0.55744\end{array}$

Gambar 2 : Uji Hipotesis untuk semua nilai $\tau$

Hasil uji hipotesis ini menunjukan pada $\tau=0.05,0.10,0.15,0.20,0.90$ dan 0.95 hanya variabel frekuensi hari hujan yang memiliki nilai signifikan. Pada $\tau=0.25$ hanya variabel frekuensi hari hujan dan suhu yang memiliki nilai signifikan. Pada $\tau=$ 0.85 hanya variabel suhu yang memiliki nilai signifikan. Sementara pada $\tau=0.30$, $0.35,0.40,0.45,0.50,0.55,0.60,0.65,0.70,0.75$ dan 0.80 variabel frekuensi hari hujan, suhu dan kelembaban memiliki nilai yang signifikan. Kesignifikan variabelvariabel tersebut dapat dilihat dari nilai-p yang lebih kecil dari $5 \%$ atau 0,05 . Sehingga dapat disimpulkan bahwa berdasarkan pada uji hipotesis tersebut, kuantil yang digunakan adalah $0.30,0.35,0.40,0.45,0.50,0.55,0.60,0.65,0.70,0.75$ dan 0.80 
karena memilki nilai signifikan disemua variabel. Maka model yang digunakan dalam pengujian ini adalah :

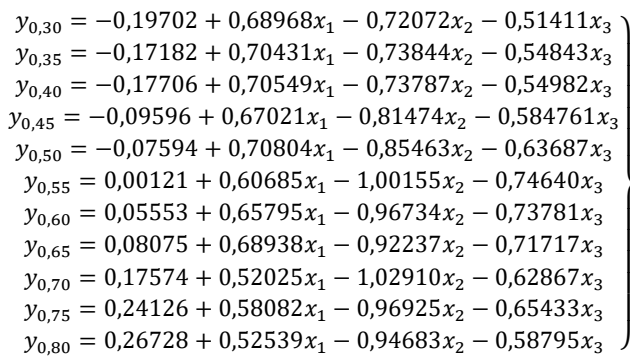

Nilai positif pada $x_{1}$ berarti dengan kenaikan 1 satuan presentase frekuensi hari hujan dan jika semua $x$ yang lain sama dengan nol maka, jumlah kasus DBD akan meningkat sebanyak 0.68968 pada kuantil $0.30,0.70431$ pada kuantil $0.35,0.70549$ pada kuantil $0.40,0.67021$ pada kuantil $0.45,0.70804$ pada kuantil $0.50,0.60685$ pada kuantil $0.55,0.65795$ pada kuantil $0.60,0.68938$ pada kuantil $0.65,0.52025$ pada kuantil $0.70,0.58082$ pada kuantil 0.75 dan 0.52539 pada kuantil 0.80 .

\section{KESIMPULAN}

Berdasarkan hasil penelitian dan pembahasan yang diperoleh, dapat diambil beberapa kesimpulan sebagai berikut:

1. Faktor kondisi alam berpengaruh terhadap penyebaran penyakit DBD. Karena setelah dilakukan pengujian terhadap 19 kuantil ternyata ada 11 kuantil yang memberikan pengaruh terhadap data yang diuji, kuantil tersebut adalah $0.30,0.35,0.40,0.45,0.50,0.55,0.60$, $0.65,0.70,0.75$ dan 0.80 .

2. Model yang didapatkan dalam pengujian :

$$
\begin{gathered}
\mathrm{y}_{0,30}=-0,19702+0,68968 \mathrm{x}_{1}-0,72072 \mathrm{x}_{2}-0,51411 \mathrm{x}_{3} \\
\mathrm{y}_{0,35}=-0,17812+0,70431 \mathrm{x}_{1}-0,73844 \mathrm{x}_{2}-0,54843 \mathrm{x}_{3} \\
\mathrm{y}_{0,40}=-0,17706+0,70549 \mathrm{x}_{1}-0,73787 \mathrm{x}_{2}-0,54982 \mathrm{x}_{3} \\
\mathrm{y}_{0,45}=-0,09596+0,67021 \mathrm{x}_{1}-0,81474 \mathrm{x}_{2}-0,584761 \mathrm{x}_{3} \\
y_{0,50}=-0,07594+0,70804 x_{1}-0,85463 x_{2}-0,63687 x_{3} \\
y_{0,55}=0,00121+0,60685 x_{1}-1,00155 x_{2}-0,74640 x_{3} \\
y_{0,60}=0,05553+0,65795 x_{1}-0,96734 x_{2}-0,73781 x_{3} \\
y_{0,65}=0,08075+0,68938 x_{1}-0,92237 x_{2}-0,71717 x_{3} \\
y_{0,70}=0,17574+0,52025 x_{1}-1,02910 x_{2}-0,62867 x_{3} \\
y_{0,75}=0,24126+0,58082 x_{1}-0,96925 x_{2}-0,65433 x_{3} \\
y_{0,80}=0,26728+0,52539 x_{1}-0,94683 x_{2}-0,58795 x_{3}
\end{gathered}
$$

Dengan kata lain jumlah kasus DBD tanpa adanya frekuensi hari hujan, suhu dan kelembaban adalah 1 satuan persentase dari intercept tiap kuantil. $x_{1}$ yang bernilai positif pada tiap kuantil berarti dengan kenaikan 1 satuan persentase frekuensi hari hujan dan variabel lainnya sama dengan nol maka jumlah kasus DBD akan meningkat sesuai nilai frekuensi hari hujan pada tiap kuantil. Sedangkan kenaikan 1 satuan persentase suhu dan kelembaban dan nol untuk variabel lainnya maka akan mengurangi jumlah kasus DBD karena $x_{2}$ dan $x_{3}$ bernilai negatif. Jadi faktor kondisi alam yang berpengaruh terhadap penyebaran penyakit DBD adalah frekuensi hari hujan. 


\section{DAFTAR PUSTAKA}

[1] Furno, M, Parameter Instability in Quantile Regressions, 2007, 7(4) : 345-362.

[2] Hao, L., \& naiman, D, Q, Quantile Regression. Sage Publications, Inc, 2007.

[3] Demam Berdarah Dengue, http://berkahmeidra.blogspot.com//, diakses tanggal 12 Oktober 2014.

[4] Koenker, R., \& Bassett, G, Quantile Regression Econometrica : journal of the Econometric Society, 46(1), 33e50, 1978.

[5] Koenker, R, W, Confidence Intervals for Regression Quantile, in P, Mandl and M, Huskova (eds.), Asymptotic Statistic, Springer-Verlag, 1994, New York, 349-359. 